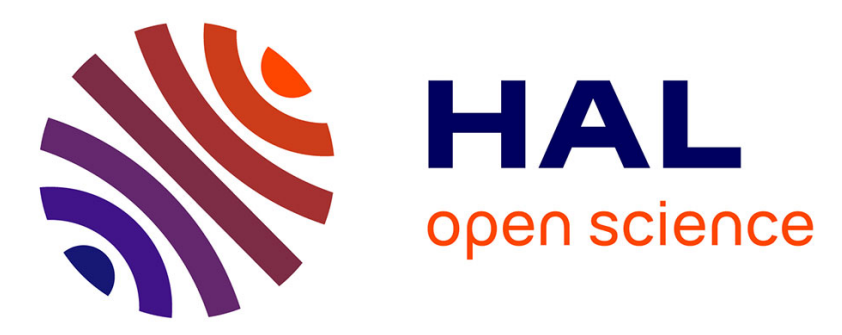

\title{
Dead-End Microfiltration of Rough Non-Alcoholic Beer by Different Polymeric Membranes
}

Mehdi Yazdanshenas, S.A.R Tabatabaei Nejad, Mohammad Soltanieh, A. Tavakkoli, A. Babaluo, Luc Fillaudeau

\section{- To cite this version:}

Mehdi Yazdanshenas, S.A.R Tabatabaei Nejad, Mohammad Soltanieh, A. Tavakkoli, A. Babaluo, et al.. Dead-End Microfiltration of Rough Non-Alcoholic Beer by Different Polymeric Membranes. Journal- American Society of Brewing Chemists, 2010, 68 (2), pp.83-88. 10.1094/ASBCJ-2010-031501 . hal-02264352

\section{HAL Id: hal-02264352 https://hal.science/hal-02264352}

Submitted on 19 Sep 2019

HAL is a multi-disciplinary open access archive for the deposit and dissemination of scientific research documents, whether they are published or not. The documents may come from teaching and research institutions in France or abroad, or from public or private research centers.
L'archive ouverte pluridisciplinaire HAL, est destinée au dépôt et à la diffusion de documents scientifiques de niveau recherche, publiés ou non, émanant des établissements d'enseignement et de recherche français ou étrangers, des laboratoires publics ou privés. 


\title{
Dead-end Microfiltration of Rough Nonalcoholic Beer by Different Polymeric Membranes
}

\author{
M. Yazdanshenas ${ }^{1}$ and S. A. R. Tabatabaei Nejad, Department of Chemical Engineering, Sahand University of \\ Technology, Tabriz, Iran; M. Soltanieh, Department of Chemical and Petroleum Engineering of Sharif University of \\ Technology, Tehran, Iran; A. Tavakkoli and A. A. Babaluo, Department of Polymer Engineering, Sahand University of \\ Technology, Tabriz, Iran; and L. Fillaudeau, Laboratoire d'Ingénierie des Systèmes Biologiques et des Procédés, CNRS \\ UMR5504, INRA UMR792, INSA, Toulouse, France
}

\section{ABSTRACT}

J. Am. Soc. Brew. Chem. 68(2):83-88, 2010

\begin{abstract}
Clarification of rough nonalcoholic beer using microfiltration as an alternative to conventional filtration with filter aids presents scientific and technical challenges for the brewing industry. An experimental pilot plant was used to evaluate the permeability and selectivity of polymeric membranes in the clarification process. Cellulose acetate (CA) with pore sizes of $0.2,0.45,0.8$, and $1.2 \mu \mathrm{m}$, together with cellulose nitrate $(\mathrm{CN})$, nylon (NY), and polytetrafluoroethylene (PTFE) with a pore size of $0.45 \mu \mathrm{m}$, were used at transmembrane pressures (TMP) of 1.0 and 2.0 bar. The data corroborated that the flux values of the $\mathrm{CA}, \mathrm{CN}$, and $\mathrm{NY}$ membranes were almost the same and reduced drastically, whereas PTFE was not permeable at $1.0 \mathrm{bar}$ and its flux at $2.0 \mathrm{bar}$ increased at the beginning and decreased after reaching a maximum. At both TMP, the $\mathrm{CN}$ membrane displayed the highest rejection of suspended particles and haze-active proteins, while retention of polyphenols and color were highest for the NY membrane. The lower selectivity of the PTFE membrane can be attributed to its hydrophobicity and less interaction with the hydrophilic haze-active proteins. The results confirmed that by increasing the pore size of CA membranes the separation factor of the sensitive proteins and suspended particles decreased and permeability increased.
\end{abstract}

Keywords: Clarification, Haze-active proteins, Malt beverage, Nonalcoholic beer, Polyphenols, Pore size

\section{RESUMEN}

Aclaración de la cerveza sin alcohol en bruto por microfiltración como una alternativa a la filtración convencional con ayudas del filtro presenta desafíos científicos y técnicos para la industria cervecera. Una planta piloto experimental fue utilizada para evaluar la permeabilidad y selectividad de las membranas poliméricas en el proceso de clarificación. El acetato de celulosa (CA), con tamaños de poro de $0.2,0.45,0.8$, y $1.2 \mu \mathrm{m}$, junto con el nitrato de celulosa $(\mathrm{CN})$, el nylon $(\mathrm{NY})$, y el politetrafluoroetileno (PTFE) con un tamaño de poro de $0.45 \mu \mathrm{m}$, se utilizaron en las presiones transmembrana (PGT) de 1.0 y 2.0 barra. Los datos corroboran que los valores de flujo de la CA, CN, y las membranas NY fueron casi los mismos y se redujeron drásticamente, mientras que el PTFE no era permeable a 1.0 barra y su flujo a 2.0 barra mayor al principio y han disminuido tras alcanzar un máximo. Por los dos PGT, la membrana CN muestra el mayor rechazo de partículas en suspensión y turbidez proteínas activas, mientras que la retención de los polifenoles y el color eran los más altos de la membrana NY. La selectividad inferior de la membrana PTFE se puede atribuir a su hidrofobicidad y menor interacción con las proteínas activa turbidez hidrofílicas. Los resultados confirmaron que al aumentar el tamaño de los poros de las membranas CA el factor de separación de las proteínas y partículas en suspensión sensible disminución y el aumento de la permeabilidad.

Palabras claves: Aclaración, Bebidas de malta, Cerveza sin alcohol, Polifenoles, Proteínas activa turbidez, Tamaño de los poros

${ }^{1}$ Corresponding author. E-mail: yazdn@yahoo.com; Phone: +98 9121134734.

doi:10.1094/ASBCJ-2010-0315-01

(c) 2010 American Society of Brewing Chemists, Inc.
Beer is the fifth most widely consumed beverage in the world and is a popular beverage, with an average consumption of $23 \mathrm{~L}$ per person per year. The consumption of nonalcoholic beer is increasing significantly due to its lower calorie content; health concerns associated with alcoholic beverages; and social, legal, and religious issues associated with alcohol in some parts of the world. This has led to the development of a market for health-promoting beverages, and most major brewers are now including alcohol-free beers in their product portfolios $(2,4,6)$. Clarification is a critical stage that involves the removal of yeast and particles to achieve a bright beer with colloidal stability. In addition, this stage reduces the microbiological count of the filtrate. Standard filtration consists of retention of solid particles during dead-end filtration with filter aids $(6,8,17,19)$. Recently, membrane technology has been successfully used in a clarification process, wherein kieselguhr filtration is replaced by crossflow microfiltration. It has been found that this technology could provide further improvements to quality, environmental, and health issues, as well as process safety, simplicity, flexibility, and operational costs $(7,11,13,17,18,23)$.

Numerous studies have been done on the use of polymeric membranes in microfiltration of beer. The first polymeric membrane used for this application was typically polypropylene. Despite its good resistance to many cleaning agents, this polymer has one main disadvantage - its hydrophobic nature. In recent years, a wide range of hydrophilic polymeric membranes have been tested for use in microfiltration (15). Czekaj et al (3) studied dead-end microfiltration of beer using hydrophilic cellulose acetate (CA) and polycarbonate (PC) membranes with a nominal pore size of $0.2 \mu \mathrm{m}$. They found that the CA membrane, which has higher surface porosity, led to a more gradual decrease in flux than did PC (3). Yokhanis et al (24) used a stirred cell with $0.45-\mu \mathrm{m}$ hydrophobic polytetrafluoroethylene (PTFE) and hydrophilic surface-modified polyethersulphone membranes to investigate the effects of membrane hydrophilicity on flux and resistance. They concluded that fouling on hydrophobic membranes was severe and involved adsorption of beer components onto the membrane surface, while surface-modified hydrophilic membranes provided higher flux (24).

Reed (15) reported on a breakthrough in the application of membranes in beer filtration in a study of the effects of membrane pore size on final product quality. Fillaudeau and Carrère (9) demonstrated that membranes with mean pore diameters $<0.2$ and $0.45 \mu \mathrm{m}$ provided high retention of essential compounds and a clear, bright, almost sterile, but insipid product (less color, dry matter, bitterness, and head-retention value). Below $0.80 \mu \mathrm{m}$, retention remained too high and induced low-value permeates. Membranes with a mean pore diameter of $\geq 0.80 \mu \mathrm{m}$ satisfied a retention rate of essential compounds of $<10 \%(8,9)$. The advantage of pore sizes $>0.4$ to $0.5 \mu \mathrm{m}$ was clear when studying the transmission of beer components, but according to prior research, application of larger pore sizes $(<1 \mu \mathrm{m})$ did not result in considerably higher flux even though flux declined at a substantially lower rate $(8,15)$. Gan et al (11) showed that chill haze in beer clarified with a ceramic membrane with a $1.3-\mu \mathrm{m}$ pore 
diameter was a potential problem of colloidal instability. On the other hand, the same membrane with a $0.2-\mu \mathrm{m}$ pore diameter was too small to allow passage of sufficient proteinaceous components for a good head-retention value. Therefore, an optimum pore diameter should be chosen according to the feed and process conditions (11). Fillaudeau et al (8) evaluated analytical profiles of the permeate and retention rate for membranes with different mean pore diameters in a rotating vibrating filtration plant. According to their research, for pore diameters $>1 \mu \mathrm{m}$ and $<3 \mu \mathrm{m}$, the clarified beer met European Brewery Convention (EBC) qualitative standards (11).

Nonalcoholic beer (NAB) contains a maximum of $0.5 \%(\mathrm{vol} / \mathrm{vol})$ alcohol, which is produced by either removal of alcohol during postfermentation or restriction of alcohol production during the brewing process. Fermentation bypass is the most common method used in areas where use of alcohol is prohibited according to religious, social, and legal restrictions or concerns about nonfermented and halal products (2). The fermentation bypass method involves a different feed to the filtration stage compared with lager beer production.

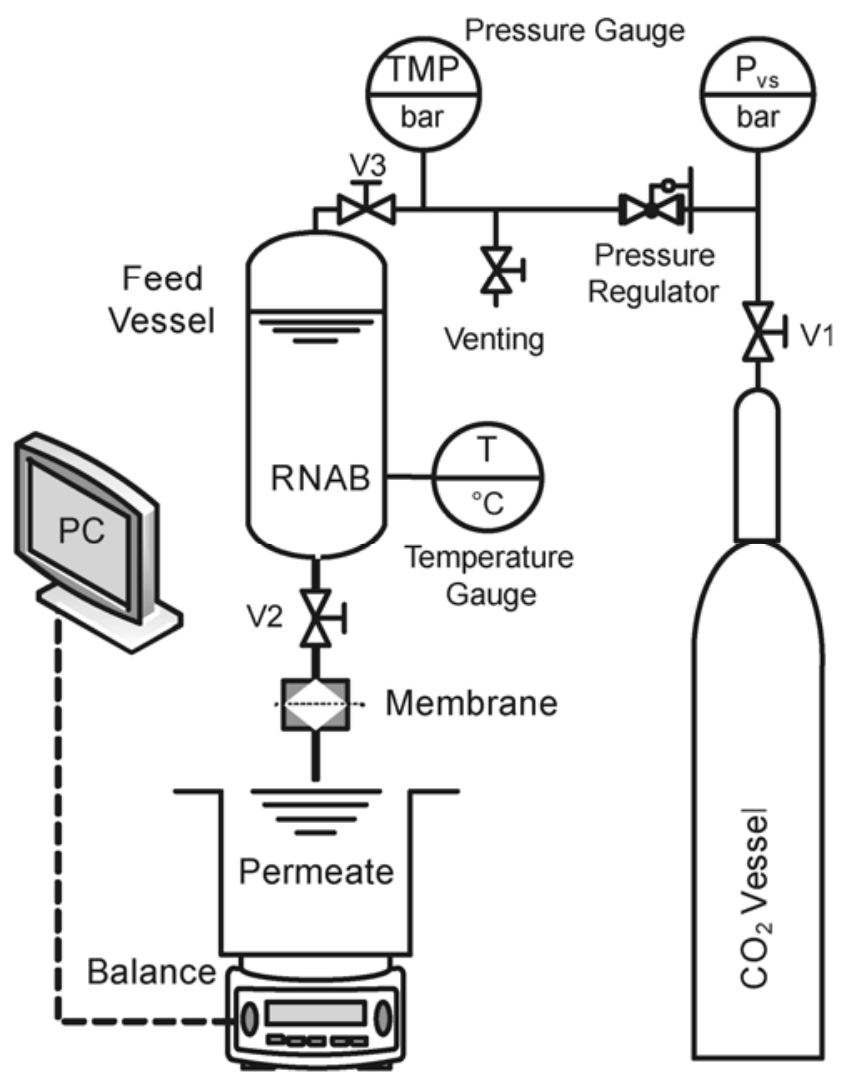

Fig. 1. Experimental dead-end microfiltration apparatus. TMP $=$ transmembrane pressure; RNAB = rough nonalcoholic beer.
In addition to the alcohol content, the yeast content of rough nonalcoholic beer (RNAB) is limited. RNAB does not contain carbon dioxide, and in the absence of biological modification, the molecular and macromolecular composition of the filtration feed (such as proteins, amino acids, and acetyls) is different. These make the physicochemical properties of this type of beer entirely distinct from lager beer. These distinctions require specific consideration in process design and operation.

Despite the long history of applied research and development in membrane clarification of lager beer and substantial differences in properties between NAB and lager beer, very few studies have been performed on the clarification process for NAB. The ever-growing market demands for NAB necessitate further work on process design of NAB brewing.

The objective of this work was to evaluate the effects of pore size and polymeric material on the permeability and selectivity of membranes in dead-end microfiltration of RNAB at two transmembrane pressures (TMP): 1.0 and 2.0 bar. For this purpose, CA membranes with pore sizes of $0.2,0.45,0.8$, and $1.2 \mu \mathrm{m}$ and cellulose nitrate $(\mathrm{CN})$, nylon (NY), and PTFE membranes with a pore size of 0.45 were used as polymeric membranes.

\section{EXPERIMENTAL}

The apparatus used in this study is shown schematically in Figure 1. It was constructed entirely of stainless steel, and the membrane module was capable of holding a flat-sheet polymeric membrane. The membrane was supported on a sintered stainless-steel plate, providing an active filtration area of $3.46 \mathrm{~cm}^{2}$. The membrane types and pore sizes used are summarized in Table I.

Before each experiment, the membranes were cut into 25-mmdiameter circles and gently placed in the module above the stainless-steel support. The module was then closed, and permeation was started by opening the feed valve above the module (V2 in Figure 1). The membranes did not go through special wetting processes, even though during the short time period after placement on the support and before opening the feed valve the membranes were only wet by the water already present on the support.

At the beginning of the experiment, with valves V2 and V3 (Fig. 1) closed, a certain amount of RNAB was filled into the feed vessel, and after adjusting the pressure by regulator, the V3 and V2 valves were opened consecutively to start the permeation. Feed temperature and TMP were measured with an accuracy of $\pm 0.1^{\circ} \mathrm{C}$ and \pm 0.05 bar, respectively. The permeate was collected in a reservoir placed on an electronic microbalance (accuracy $\pm 0.1 \mathrm{~g}$; model GP 5202, Sartorius) interfaced to a PC to collect and record mass versus time data (every $0.4 \mathrm{sec}$ ). The permeate flux was obtained by numerical differentiation of the filtrate volume versus time data.

The NAB for this study was produced, using the fermentation bypass process, from pure malt (provided by Iran Behnoush Co., Tehran, Iran). The RNAB was prepared by taking samples from the

TABLE I

Polymeric Membranes Used in This Study ${ }^{\mathrm{a}}$

\begin{tabular}{|c|c|c|c|c|c|}
\hline Membrane Material & $\begin{array}{c}\text { Nominal } \\
\text { Pore Size }(\mu \mathrm{m})\end{array}$ & Thickness $(\boldsymbol{\mu m})$ & $\begin{array}{c}\text { Water Permeability } \\
\text { at } \mathrm{TMP}=1.0 \mathrm{bar}\left(\mathrm{L} / \mathrm{m}^{2} \cdot \mathrm{hr}\right)\end{array}$ & $\begin{array}{l}\text { Bubble Point } \\
\text { (bar) }\end{array}$ & Manufacturer \\
\hline Cellulose acetate & 0.2 & 120 & 14,400 & $>2.9$ & ALBET \\
\hline Cellulose acetate & 0.45 & 120 & 41,400 & 1.9 & ALBET \\
\hline Cellulose acetate & 0.8 & 120 & 120,000 & 0.8 & ALBET \\
\hline Cellulose acetate & 1.2 & 140 & 228,000 & NA & $\mathrm{M} \& \mathrm{~N}$ \\
\hline Cellulose nitrate & 0.45 & 130 & 41,400 & 2.4 & $\mathrm{M} \& \mathrm{~N}$ \\
\hline Polytetrafluoroethylene & 0.45 & 65 & 180 & 0.7 & ALBET \\
\hline Nylon & 0.45 & 115 & 15,600 & 2.2 & ALBET \\
\hline
\end{tabular}

a $\mathrm{TMP}=$ transmembrane pressure $\mathrm{NA}=$ not available . 
upper part of the conditioning vessel and adjusting them to the desired concentration. Physical and chemical measurements were performed on collected permeate samples during experiments according to EBC protocols (5). This included measurement of haze-turbidity (EBC method 9.29), sensitive proteins (EBC method 9.40), total polyphenols (EBC method 9.11), and color (EBC method 9.6). The soluble solids concentration of feeds was adjusted to $3.8 \pm 0.1^{\circ} \mathrm{Bx}$, which was determined by digital refractometer (model PR-32 $\alpha$, Atago Co., Ltd.). The haze was determined in nephelometric turbidity unit (NTU) scales using a portable turbidimeter (model 2100P, Hach). Each permeation experiment was $90 \mathrm{~min}$ long, and the rejection values were calculated from total permeate over feed parameters.

\section{RESULTS AND DISCUSSIONS}

\section{Overview of Filtration Runs}

The comparative effects of the type of membrane materials used were evaluated for membranes of the same pore size $(0.45 \mu \mathrm{m})$ at TMP of 1.0 and 2.0 bar. For evaluation of the effects of pore size on qualitative and quantitative parameters in RNAB clarification, CA membranes with pore diameters of $0.2,0.45,0.8$, and $1.2 \mu \mathrm{m}$ were tested at a TMP of 1.0 bar. A summary of the results is presented in Table II in the form of maximum flux $\left(J_{\max }\right)$, its average in the first $20 \mathrm{~min}$ of operation $\left(J_{20 \mathrm{~min}}\right)$, and qualitative parameters for feed and permeate. The repetition of the experiments and standard deviation of the results are presented in Table II (25).

TABLE II

Summary of Feed Parameters Measured and Quantitative and Qualitative Results for Polymeric Membrane Materials Tested ${ }^{\mathrm{a}}$

\begin{tabular}{|c|c|c|c|c|c|c|c|c|c|c|c|c|c|}
\hline \multirow[b]{2}{*}{ Parameter $^{\mathrm{b}}$} & \multirow{2}{*}{$\begin{array}{c}\text { No. of } \\
\text { Tests }\end{array}$} & \multicolumn{2}{|c|}{$\begin{array}{c}J_{\max } \\
\left(\mathbf{L} / \mathbf{m}^{2} \cdot \mathbf{h r}\right)\end{array}$} & \multicolumn{2}{|c|}{$\begin{array}{c}J_{20 \min } \\
\left(\mathbf{L} / \mathbf{m}^{2} \cdot \mathbf{h r}\right)\end{array}$} & \multicolumn{2}{|c|}{ Haze (NTU) } & \multicolumn{2}{|c|}{ Color (EBC) } & \multicolumn{2}{|c|}{$\begin{array}{c}\text { Sensitive Proteins } \\
\text { (NTU) }\end{array}$} & \multicolumn{2}{|c|}{$\begin{array}{c}\text { Polyphenols } \\
\text { (mg/L) }\end{array}$} \\
\hline & & Avg. & SD & Avg. & SD & Avg. & SD & Avg. & SD & Avg. & SD & Avg. & SD \\
\hline Feed & - & - & - & - & - & 74.69 & 25.0 & 3.00 & 0.00 & 78.1 & 18.5 & 63.45 & 15.4 \\
\hline \multicolumn{14}{|l|}{$\mathrm{TMP}=1.0 \mathrm{bar}$} \\
\hline $0.2-\mu \mathrm{m} \mathrm{CA}$ & 1 & 5,980 & - & 2,016 & - & 2.25 & - & 2.50 & - & 23.1 & - & - & - \\
\hline $0.45-\mu \mathrm{m} \mathrm{CA}$ & 5 & 8,256 & 1,165 & 2,930 & 889 & 2.61 & 1.45 & 2.60 & 0.14 & 58 & 29.7 & 63 & 8.5 \\
\hline $0.8-\mu \mathrm{m} \mathrm{CA}$ & 3 & 38,961 & 1,202 & 12,191 & 1,411 & 7.08 & 0.92 & 2.75 & 0.21 & 82 & 3.2 & 56 & - \\
\hline $1.2-\mu \mathrm{m} \mathrm{CA}$ & 2 & 51,668 & 1,278 & 12,647 & 1,084 & 7.06 & 0.62 & 2.80 & 0.00 & 78 & 1.4 & 51 & - \\
\hline $0.45-\mu \mathrm{m} \mathrm{CN}$ & 2 & 7,511 & 1,669 & 2,844 & 899 & 1.68 & 0.11 & 2.50 & - & 58 & - & 66 & - \\
\hline $0.45-\mu \mathrm{m} N Y$ & 1 & 3,795 & - & 1,740 & - & 3.21 & - & 2.50 & - & 60 & - & 32 & - \\
\hline $0.45-\mu \mathrm{m}$ PTFE & 2 & - & - & - & - & - & - & - & - & - & - & - & - \\
\hline \multicolumn{14}{|l|}{$\mathrm{TMP}=2.0 \mathrm{bar}$} \\
\hline $0.45-\mu \mathrm{m} \mathrm{CA}$ & 3 & 18,327 & 998 & 6,857 & 1,530 & 2.2 & 0.76 & 2.65 & 0.21 & 75 & 3.5 & 76 & - \\
\hline $0.45-\mu \mathrm{m} \mathrm{CN}$ & 1 & 12,326 & - & 5,631 & - & 1.33 & - & 2.50 & - & 56 & - & 48 & - \\
\hline $0.45-\mu \mathrm{m} N Y$ & 1 & 15,323 & - & 6,712 & - & 1.45 & - & 2.20 & - & 60 & - & 31 & - \\
\hline $0.45-\mu \mathrm{m}$ PTFE & 3 & 120 & 35 & 21 & 35 & 2.27 & 0.64 & 2.75 & 0.07 & 77 & 15.9 & 56 & - \\
\hline
\end{tabular}

a $J_{\max }=$ maximum flux; $J_{20 \min }=$ average flux in first 20 min of operation; NTU = nephelometric turbidity unit.

b $\mathrm{TMP}=$ transmembrane pressure $\mathrm{CA}=$ cellulose acetate $\mathrm{CN}=$ cellulose nitrate; $\mathrm{NY}=$ nylon; and $\mathrm{PTFE}=$ polytetrafluoroethylene membranes .
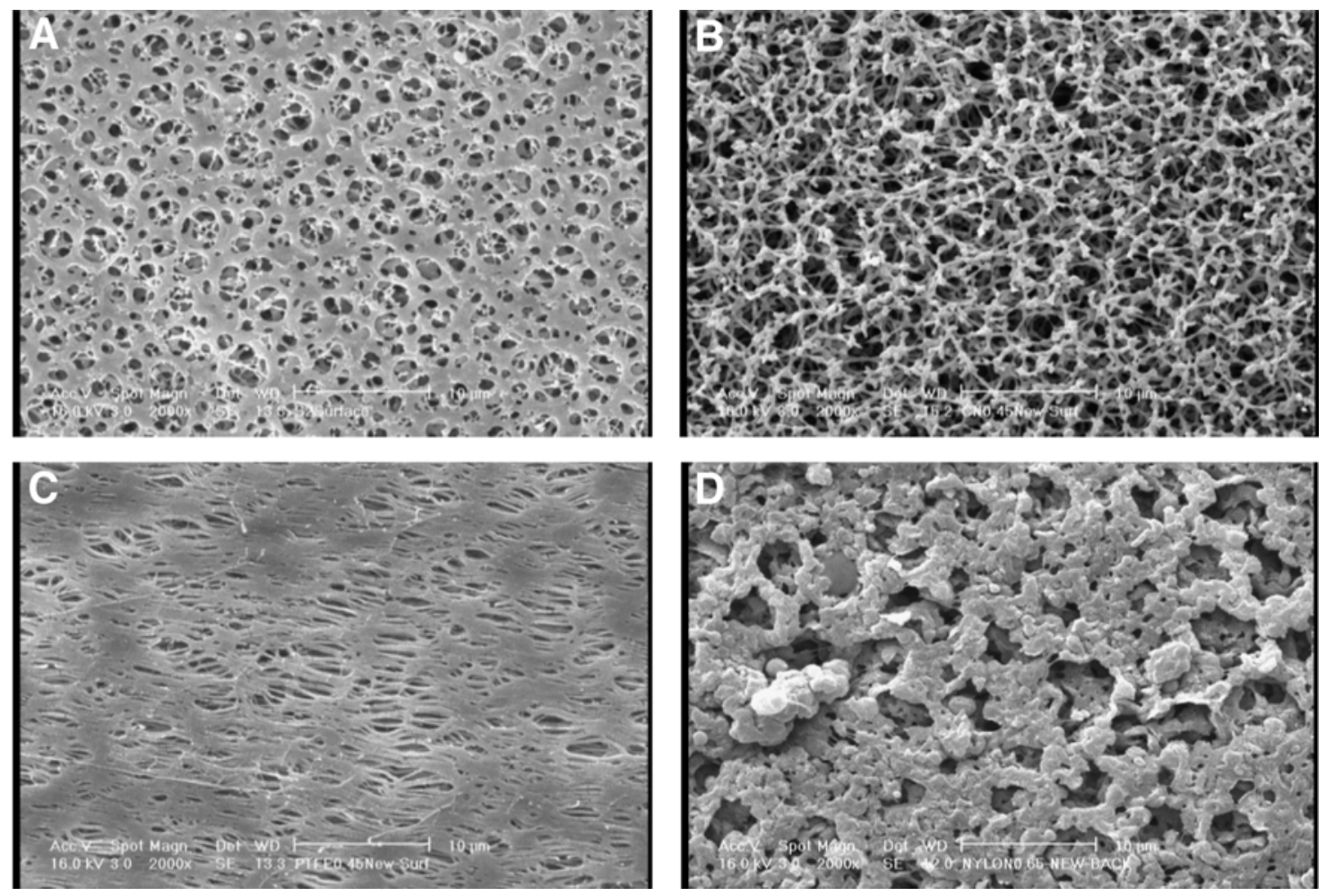

Fig. 2. Scanning electron microscope images of new polymeric membranes: A, cellulose acetate $(0.45 \mu \mathrm{m})$; $\mathbf{B}$, cellulose nitrate $(0.45 \mu \mathrm{m})$; $\mathbf{C}$, polytetrafluoroethylene $(0.45 \mu \mathrm{m})$; and $\mathbf{D}$, nylon $(0.65 \mu \mathrm{m})$. 

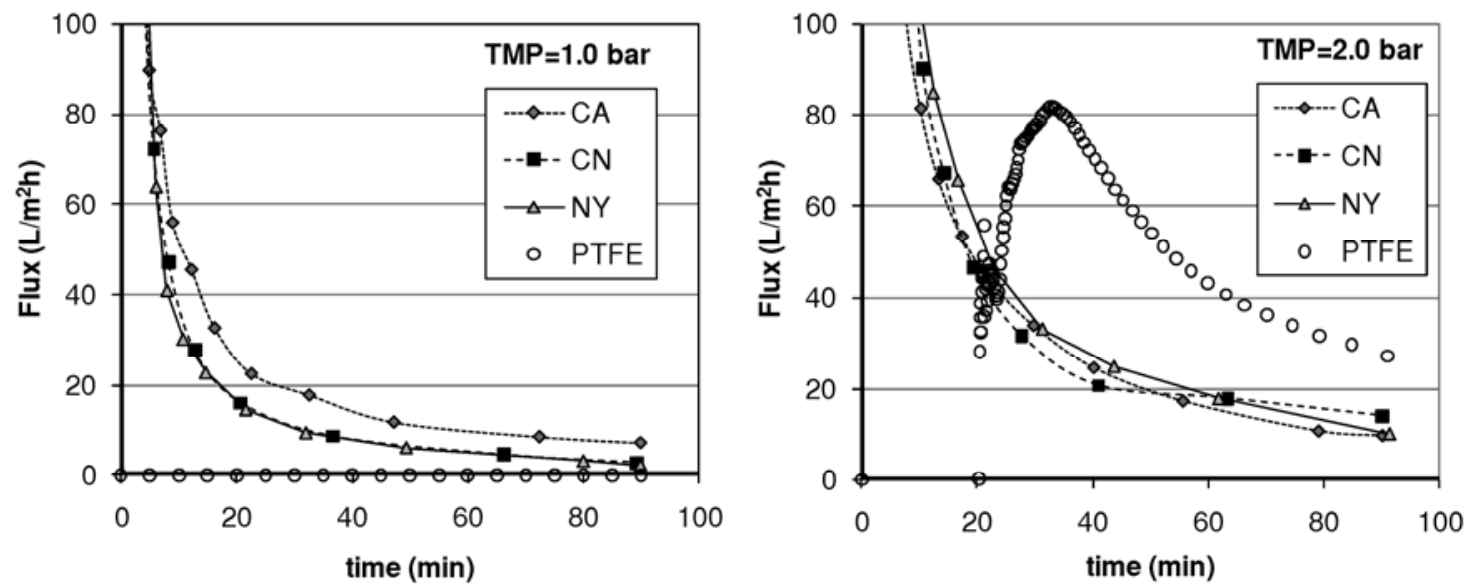

Fig. 3. Flux behavior of different polymeric membranes $(\mathrm{CA}=$ cellulose acetate, $\mathrm{CN}=$ cellulose nitrate, $\mathrm{NY}=$ nylon, and PTFE $=$ polytetrafluoroethylene $)$ with a pore diameter of $0.45 \mu \mathrm{m}$ under transmembrane pressure (TMP) of 1 or 2 bar.
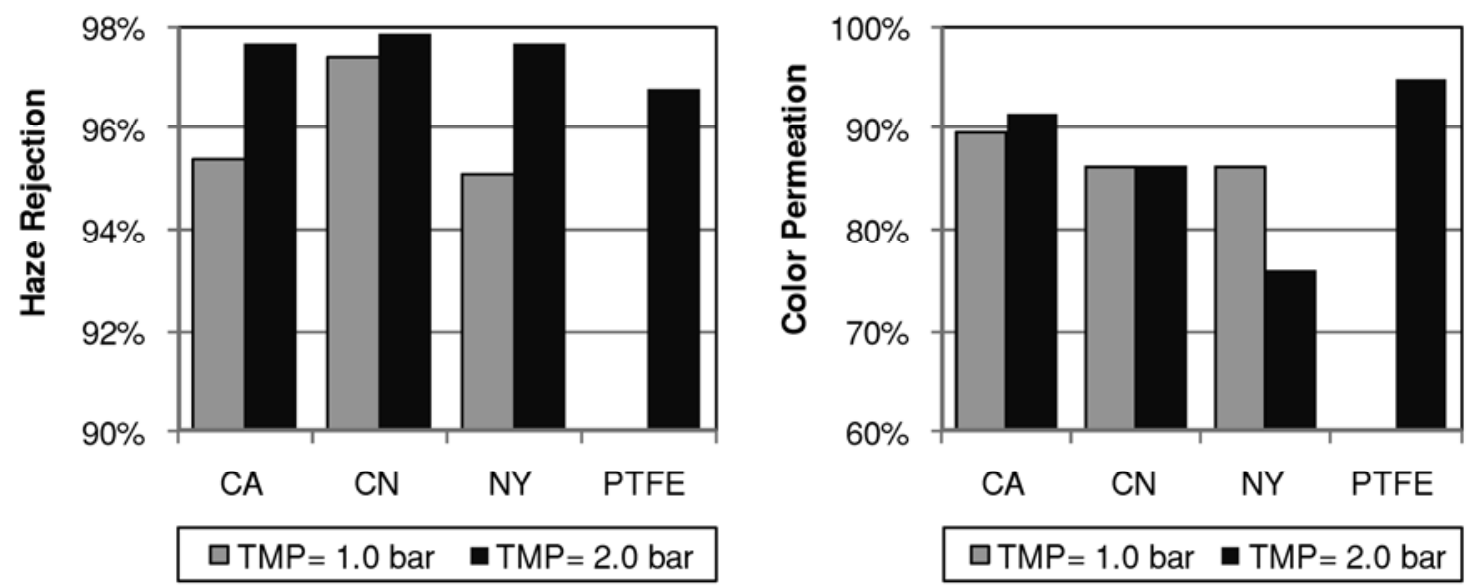

Fig. 4. Turbidity rejection and color permeation obtained with different polymeric membranes $(\mathrm{CA}=$ cellulose acetate, $\mathrm{CN}=$ cellulose nitrate, $\mathrm{NY}=$ nylon, and PTFE = polytetrafluoroethylene) with a pore diameter of $0.45 \mu \mathrm{m}$ under transmembrane pressure (TMP) of 1 or 2 bar.

According to Table II at a TMP of $1.0 \mathrm{bar}, 1.2-\mu \mathrm{m}$ CA had the highest flux and was one order of magnitude higher compared with that of $0.45-\mu \mathrm{m}$ CA. However, the turbidity of the permeates from membranes with larger pore sizes $(0.8$ and $1.2 \mu \mathrm{m})$ were higher and approached the upper limit of 8.0 NTU (equivalent to 2 EBC) (12). Moreover, the more highly sensitive (haze active) proteins in the permeates would cause colloidal instability in the product $(1,21)$. Among different types of membranes with the same pore size, $0.45-\mu \mathrm{m}$ CA had the highest permeation with both TMP; $0.45-\mu \mathrm{m}$ PTFE did not have any permeate at a TMP of 1.0 bar, and its flux at a TMP of 2.0 bar was far less than was observed for the other membrane materials. Turbidity and sensitive protein content were lowest for $0.45-\mu \mathrm{m} \mathrm{CN}, \mathrm{CA}$ and PTFE showed better color permeation, and NY had the lowest content of polyphenols in the permeate. Scanning electron microscopy illustrated the structural differences among the membranes (Fig. 2).

\section{Effects of Polymeric Membrane Material}

Permeation flux behavior through different polymeric membranes with a pore diameter of $0.45 \mu \mathrm{m}$ is shown in Figure 3. According to this results, at a TMP of 1.0 bar, CN and NY membrane flux behaviors were the same, CA had higher permeation flux, and PTFE did not show any permeation. At a TMP of 2.0 bar, there was no significant difference between the flux behavior of CA, CN, or NY, but PTFE behaved quite differently and unexpectedly. The flux behavior of PTFE membrane at a TMP of 2 bar increased initially and, after reaching a maximum of approx. $80 \mathrm{~L} / \mathrm{m}^{2} \cdot \mathrm{hr}$, decreased. This phenomenon can be attributed to a shift in hydrophobicity in the PTFE matrix during filtration. The data corroborate the theory that under high pressure hydrophilic sites or zones began to develop within the matrix, which initially increased the flux and through filtration fouling eventually caused a drop in flux.

The objective of the clarification stage is to maintain the color while removing the maximum amount of haze-active proteins and particles $(8,11)$. The average turbidity rejection and color permeation at two TMP (1.0 and 2.0 bar) for all four types of membranes with a pore diameter of $0.45 \mu \mathrm{m}$ is shown in Figure 4. According to the results, the $0.45-\mu \mathrm{m} \mathrm{CN}$ membrane had the highest turbidity rejection at both TMP. Turbidity rejection increased at higher pressure for all four membranes (Fig. 4). This can be attributed to the compression of the filtration cake formed on the membrane, which acts as a secondary membrane and increases selectivity. CA and PTFE had better color permeation at both TMP compared with NY.

The colloidal stability of beer depends primarily on its haze-active (sensitive) proteins and polyphenol content $(1,14,20,21)$. The effects of four membrane materials with a pore size diameter of $0.45 \mu \mathrm{m}$ on the retention of these components at two TMP (1.0 and 2.0 bar) are shown in Figure 5. $\mathrm{CN}$ had the highest rejection of sensitive proteins at both pressures (Fig. 5). Despite low selectivity of sensitive proteins by NY, it had the highest rejection of polyphenols, due to the adsorptive property of NY to the polyphenols, which has been reported previously $(10,11,16,19,22)$. The retention 

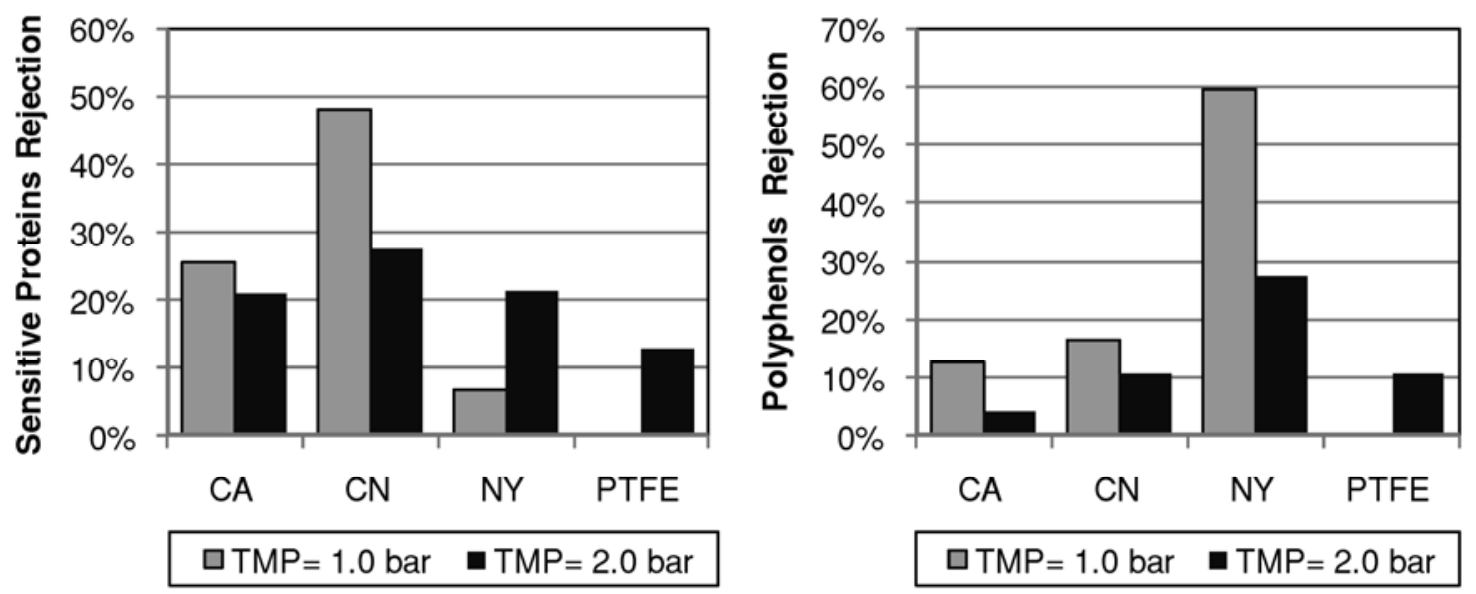

Fig. 5. Rejection of haze-active materials from rough nonalcoholic beer with different polymeric membranes $(\mathrm{CA}=$ cellulose acetate, $\mathrm{CN}=$ cellulose nitrate, $\mathrm{NY}=$ nylon, and PTFE $=$ polytetrafluoroethylene) with a pore diameter of $0.45 \mu \mathrm{m}$ under transmembrane pressure (TMP) of 1 or 2 bar.

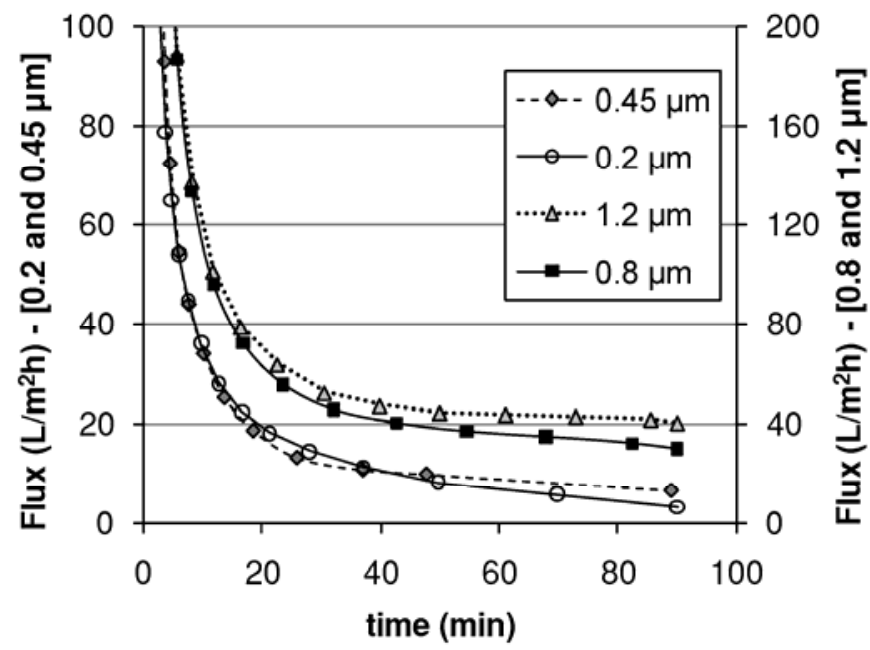

Fig. 6. Flux behavior of cellulose acetate membrane with different pore sizes at a transmembrane pressure of 1.0 bar.

of polyphenols was low for the other membranes and reduced at the higher pressure, indicating that the formation of the cake layer (acting as a secondary membrane) and its compactness at higher pressure did not influence the rejection of polyphenols. This may be due to the mechanism of polyphenol retention, which seems to be mainly adsorption on the membrane. The lowest rejection of sensitive proteins at a TMP of 2.0 bar was found for PTFE, which could be due to the hydrophobic nature of the PTFE and less interaction with hydrophilic haze-active proteins. This explanation agrees with previous work done on the subject $(10,11)$.

\section{Effects of Membrane Pore Size}

The performance of CA membranes with pore sizes of $0.2,0.45$, 0.8 , and $1.2 \mu \mathrm{m}$ with regard to flux behavior and product quality was observed. Flux values for $0.2-$ and $0.45-\mu \mathrm{m}$ CA were almost the same but much lower than those of 0.8- and 1.2- $\mu$ m CA (Fig. 6). In spite of this significant difference, the changes in relative flux (the ratio of flux to maximum flux, which normally occurs at the beginning of microfiltration) were quite similar (Fig. 7). Relative flux was higher for smaller pore sizes, whereas larger pore size led to a higher rate of flux reduction (Fig. 7), which indicates that fouling was higher for larger pore diameters.

The effects of CA pore diameter on selectivity for turbidity, color, sensitive proteins, and polyphenols are shown in Figure 8. Accord-

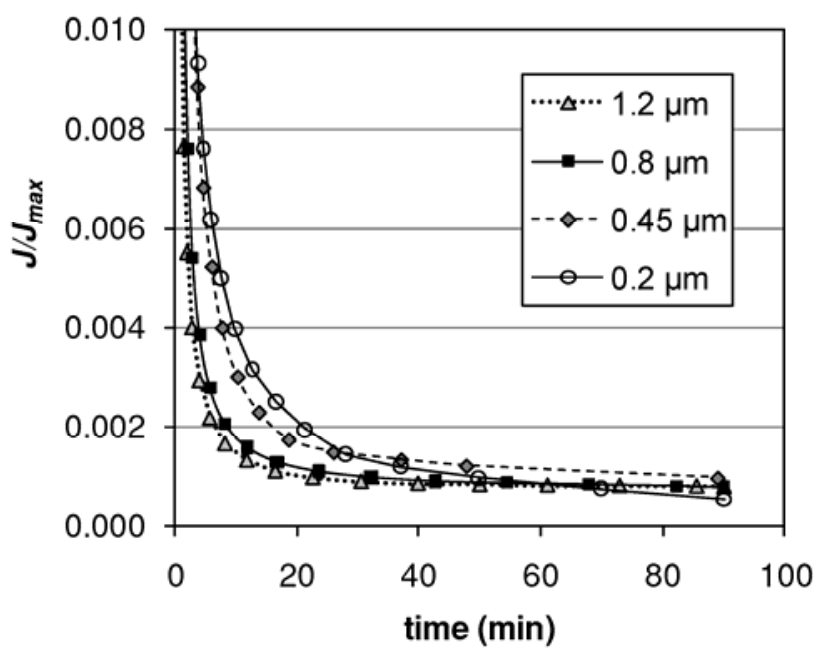

Fig. 7. Relative flux of cellulose acetate membrane with different pore sizes at a transmembrane pressure of 1.0 bar.

ing to the results, rejection for all components (other than polyphenols) increased with smaller pore sizes. Turbidity retention for membranes with pore sizes of 0.2 and $0.45 \mu \mathrm{m}$ was almost the same and higher than those membranes with pore sizes of 0.8 and $1.2 \mu \mathrm{m}$, but color permeation increased almost linearly with increasing pore size. Larger pore sizes $(0.8$ and $1.2 \mu \mathrm{m})$ did not have a large effect on sensitive (haze-active) proteins, but with smaller pore sizes of 0.45 and $0.2 \mu \mathrm{m}$, rejection of these proteins increased.

\section{CONCLUSIONS}

In this study the effects of the membrane material and pore size of polymeric membranes on permeability and selectivity in deadend microfiltration of RNAB were observed and analyzed. An experimental pilot plant was used to evaluate CA membranes with pore sizes of $0.2,0.45,0.8$, and $1.2 \mu \mathrm{m}$ and $\mathrm{CN}$, PTFE, and NY membranes with a pore size of $0.45 \mu \mathrm{m}$ at two TMP (1.0 and $2.0 \mathrm{bar}$ ).

Flux values for $\mathrm{CA}, \mathrm{CN}$, and NY membranes with a pore size of $0.45 \mu \mathrm{m}$ were almost the same at the two TMP, with CA showing slightly higher flux behavior. As an unexpected result, the $0.45-\mu \mathrm{m}$ PTFE membrane did not allow any permeation at a TMP of $1.0 \mathrm{bar}$, whereas at a TMP of 2.0 bar, flux increased initially and, after reaching a maximum of approx. $80 \mathrm{~L} / \mathrm{m}^{2} \cdot \mathrm{hr}$, decreased to a final flux value similar to the other membranes. This behavior can be attributed to 

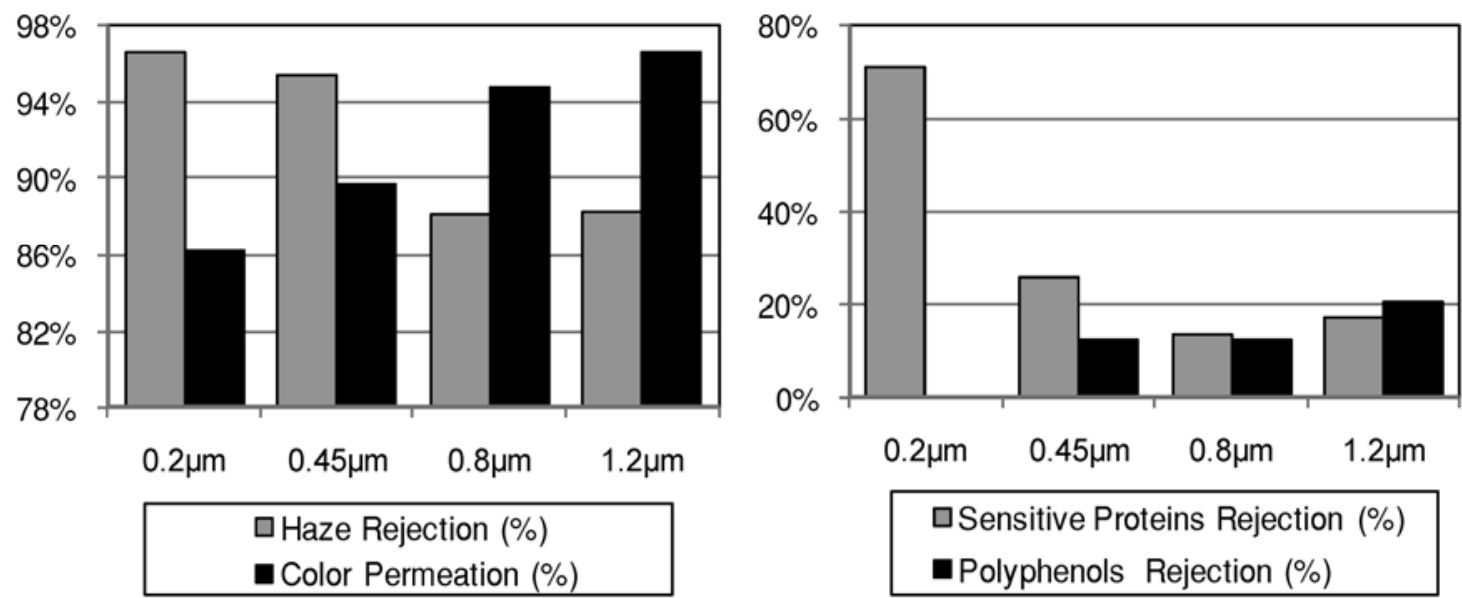

Fig. 8. Selectivity of cellulose acetate membrane with different pore sizes at a transmembrane pressure of 1.0 bar.

the hydrophobicity of the PTFE membrane and formation of hydrophilic sites during permeation. Despite the higher flux value for CA with 1.2- and $0.8-\mu \mathrm{m}$ pore sizes than for those with $0.45-$ and $0.2-\mu \mathrm{m}$ pore sizes, the flux ratio to maximum flux was higher for the $\mathrm{CA}$ membranes with smaller pore sizes.

$\mathrm{CN}$ had the highest rejection for turbidity and haze-active proteins, NY retained the most polyphenols, and CA had the highest color permeation. Higher pressure led to better turbidity removal, which could be due to the compression of the cake layer and the resultant increase in selectivity for suspended particles. Pore size had a diminishing effect on selectivity for turbidity and sensitive proteins, even though it had no obvious effect on polyphenol retention. Color permeation increased with the pore diameter of the CA membrane.

\section{ACKNOWLEDGMENTS}

This project was funded by the Iranian Ministry of Industries and Mines (Applied Research Project). We would like to thank the management of Iran Behnoush Co., K. Bayrami for his support, and A. R. Bakhtiari for his professional advice.

\section{LITERATURE CITED}

1. Bamforth, C. W. Beer haze. J. Am. Soc. Brew. Chem. 57:81-90, 1999.

2. Briggs, D. E., Boulton, C. A., Brookes, P. A., and Stevens, R. Brewing: Science and Practice. Woodhead Publishing Limited, Cambridge, 2004.

3. Czekaj, P., López, F., and Güell, C. Membrane fouling during microfiltration of fermented beverages. J. Membr. Sci. 166:199-212, 2000.

4. Euromonitor. The World Market for Beer. Euromonitor International, London, 2006.

5. European Brewery Convention. Analytica-EBC. Section 9 Beer Method 9.6 Colour of beer: Spectrophotometric method; 9.11 Total polyphenols in beer by spectrophotometry; 9.29 Haze in beer: Calibration of haze meters; 9.40 Sensitive proteins in beer by nephelometry. Fachverlag Hans Carl, Nürenberg, Germany, 1998.

6. European Brewery Convention. Beer Filtration, Stabilization and Sterilization: Manual of Good Practice. Fachverlag Hans Carl, Nürenberg, Germany, 1999.

7. Fillaudeau, L., Blanpain-Avet, P., and Daufin, G. Water, wastewater and waste management in brewing industries. J. Clean. Prod. 14:463471, 2006.

8. Fillaudeau, L., Boissier, B., Moreau, A., Blanpain-Avet, P., Ermolaev, S., Jitariouk, N., and Gourdon, A. Investigation of rotating and vibrating filtration for clarification of rough beer. J. Food Eng. 80:206-217, 2007.

9. Fillaudeau, L., and Carrère, H. Yeast cells, beer composition and mean pore diameter impacts on fouling and retention during cross-flow filtra- tion of beer with ceramic membranes. J. Membr. Sci. 196:39-57, 2002.

10. Gan, Q., Howell, J. A., Field, R. W., England, R., Bird, M. R., and McKechnie, M. T. Synergetic cleaning procedure for a ceramic membrane fouled by beer microfiltration. J. Membr. Sci. 155:277-289, 1999.

11. Gan, Q., Howell, J. A., Field, R. W., England, R., Bird, M. R., O'Shaughnessy, C. L., and McKechnie, M. T. Beer clarification by microfiltration-Product quality control and fractionation of particles and macromolecules. J. Membr. Sci. 194:185-196, 2001.

12. ISIRI. Non-alcoholic Malt Beverage. Institute of Standards and Industrial Research of Iran, Tehran, 2007.

13. Jin, Y.-L., Speers, R. A., Paulson, A. T., and Stewart, R. J. Effect of $\beta$-glucans and process conditions on the membrane filtration performance of beer. J. Am. Soc. Brew. Chem. 62:117-124, 2004.

14. Kühbeck, F., Back, W., and Krottenthaler, M. Influence of lauter turbidity on wort composition, fermentation performance and beer quality-A review. J. Am. Soc. Brew. Chem. 112:215-221, 2006.

15. Reed, R. Current and future roles of membranes in brewing. Membr. Technol. 1998(101):5-8, 1998.

16. Rehmanji, M., Narayanan, A., Mola, K., and Gopal, C. Superior colloidal stabilization of beer by combined treatment with silica (Xerogel) and PVPP, Polyclar plus 730. Tech. Q. Master Brew. Assoc. Am. 37:113-118, 2000.

17. Sadosky, P., and Schwarz, P. B. Effect of arabinoxylans, $\beta$-glucans, and dextrins on the viscosity and membrane filterability of a beer model solution. J. Am. Soc. Brew. Chem. 60:153-162, 2002.

18. Schuurman, R., Broens, L., Mepschen, A., and Meijer, D. Full scale results of (kieselguhr free) beer membrane filtration and latest developments on combined membrane filtration and stabilisation. In: Proceedings of the 10th Brewing Convention, Pilanesberg, South Africa, 2005.

19. Siebert, K. J., and Lynn, P. Y. Mechanisms of beer colloidal stabilization. J. Am. Soc. Brew. Chem. 55:73-77, 1997.

20. Siebert, K. J., and Lynn, P. Y. Effect of protein-polyphenol ratio on the size of haze particles. J. Am. Soc. Brew. Chem. 58:117-123, 2000.

21. Siebert, K. J., and Lynn, P. Y. Comparison of methods for measuring protein in beer. J. Am. Soc. Brew. Chem. 63:163-170, 2005.

22. Siebert, K. J., and Lynn, P. Y. On the mechanisms of adsorbent interactions with haze-active proteins and polyphenols. J. Am. Soc. Brew. Chem. 66:48-54, 2008

23. Yazdanshenas, M., Tabatabaeenezhad, A. R., Roostaazad, R., and Khoshfetrat, A. B. Full scale analysis of apple juice ultrafiltration and optimization of diafiltration. Sep. Purif. Technol. 47:52-57, 2005.

24. Yokhanis, M., Harris, J. L., and Rogers, P. Investigation of membrane fouling in the microfiltration of beer. In: Proceedings of the 5th International Membrane Science and Technology Conference, Sydney, Australia, 2003.

25. Zheng, F., Li, C., Yuan, Q., and Vriesekoop, F. Influence of molecular shape on the retention of small molecules by solvent resistant nanofiltration (SRNF) membranes: A suitable molecular size parameter. $J$. Membr. Sci. 318:114-122, 2008. 